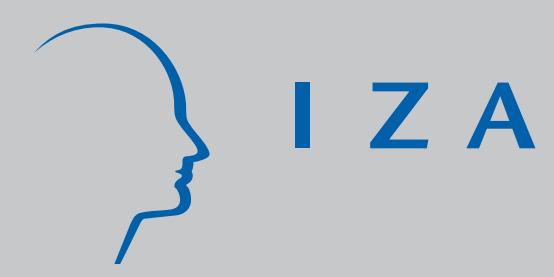

IZA DP No. 3902

Politicians' Outside Earnings and Political Competition

J ohannes Becker

Andreas Peichl

J ohannes Rincke

December 2008 


\title{
Politicians' Outside Earnings and Political Competition
}

\author{
Johannes Becker \\ University of Oxford
}

Andreas Peichl

$I Z A$

Johannes Rincke

University of Munich

\section{Discussion Paper No. 3902 \\ December 2008}

\author{
IZA \\ P.O. Box 7240 \\ 53072 Bonn \\ Germany \\ Phone: +49-228-3894-0 \\ Fax: +49-228-3894-180 \\ E-mail: iza@iza.org
}

Any opinions expressed here are those of the author(s) and not those of IZA. Research published in this series may include views on policy, but the institute itself takes no institutional policy positions.

The Institute for the Study of Labor (IZA) in Bonn is a local and virtual international research center and a place of communication between science, politics and business. IZA is an independent nonprofit organization supported by Deutsche Post World Net. The center is associated with the University of Bonn and offers a stimulating research environment through its international network, workshops and conferences, data service, project support, research visits and doctoral program. IZA engages in (i) original and internationally competitive research in all fields of labor economics, (ii) development of policy concepts, and (iii) dissemination of research results and concepts to the interested public.

IZA Discussion Papers often represent preliminary work and are circulated to encourage discussion. Citation of such a paper should account for its provisional character. A revised version may be available directly from the author. 
IZA Discussion Paper No. 3902

December 2008

\section{ABSTRACT}

\section{Politicians' Outside Earnings and Political Competition}

This paper deals with the impact of electoral competition on politicians' outside earnings. In our framework, politicians face a tradeoff between allocating their time to political effort or to an alternative use generating outside earnings. The main hypothesis is that the amount of time spent on outside work is negatively related to the degree of electoral competition. We test this hypothesis using a new dataset on outside earnings of members of the German federal assembly. Taking into account the potential endogeneity of measures of political competition that depend on past election outcomes, we find that politicians facing low competition have substantially higher outside earnings.

JEL Classification: D72, J45

Keywords: political competition, outside earnings, political rents

Corresponding author:

Johannes Becker

Centre for Business Taxation

Saïd Business School

University of Oxford

Park End Street

Oxford OX1 HP

United Kingdom

E-mail: johannes.becker2@sbs.ox.ac.uk

\footnotetext{
* We would like to thank William F. Shughart II and two anonymous referees for a number of insightful suggestions to improve our work and Clemens Fuest for valuable comments on an earlier draft. We also thank Dirk Neumann and Sebastian Siegloch for outstanding research assistance.
} 


\section{Introduction}

The conflict of interests between voters as principals and elected politicians as agents is an old theme. While voters are concerned with electing competent representatives, they cannot directly observe effort and ability. In general, this lack of monitoring and the resulting asymmetric information allows elected politicians to extract rents or simply to shirk. Political rents may take various forms, such as pork-barrel projects, corruption, or slack to cultivate private affairs. The most important mechanism that helps voters to keep elected officials accountable for their actions (i.e. to reduce the extent of rent extraction and shirking) is electoral competition. While there is a sizable theoretical literature on the effects of different electoral rules on the level of rent extraction ${ }^{1}$ and a number of empirical studies using macro data $^{2}$, there are few empirical studies that provide micro-evidence on the relation between forms and intensity of electoral competition and the behavior of politicians.

One potentially important dimension of diverging interests between elected representatives and voters is the opportunity of politicians to engage in private sector activities to earn outside income. Interestingly, in most democracies elected politicians such as members of parliament can legally work in the private sector. It has been noted that the opportunity of elected officials to keep private sector jobs and corresponding income may well have positive effects on the overall quality of policymaking. For instance, if high-ability citizens can keep outside earnings while appointed in parliament, they will be more likely to run for public office. Hence, outside earnings may increase the average quality of politicians (Gagliarducci et al., 2007). In contrast, for given ability, if politicians devote part of their time to private sector work, this will tend to reduce the quality of policymaking. ${ }^{3}$

This paper uses micro-data to investigate the role of electoral competition for the tradeoff between political activities and work that generates outside earnings. The general idea behind this is straightforward: While voters usually cannot observe the amount of time devoted to outside work, they can punish politicians for neglecting their responsibilities and pursuing their private business by voting them out of office. Consequently, when deciding on the optimal level of private sector activities, elected politicians will weigh the gains from outside work against the increased risk of not getting reelected. If electoral competition is low, the probability of reelection is high, and the marginal benefit from political activity is low. In contrast, if competition is fierce and electoral races are close, the marginal benefit

\footnotetext{
${ }^{1}$ See e.g. Persson and Tabellini (1999, 2000) and Myerson (1993).

${ }^{2}$ Examples are Persson and Tabellini (2003), Kunicova and Rose-Ackerman (2005) as well as MilesiFerretti et al. (2002).

${ }^{3}$ We do not discuss the case where politicians are influenced by or even get financially dependent on special interest groups. For related evidence, see Couch et al. (1992), analyzing how politicians who are on the payroll of higher education institutions affect public funding per college student.
} 
of political work tends to be high. Consequently, electoral competition affects the tradeoff between political activity and work in the private sector. If competition gets stronger, politicians re-allocate time from outside work towards political activity, and outside earnings decrease. In this perspective, electoral competition limits political rents.

As our main contribution to the literature, we test the hypothesis that politicians facing strong political competition devote less time to outside work. Using a unique dataset covering all members of the German Bundestag and providing detailed information on outside earnings for the years 2005-07, we test whether the degree of electoral competition has any effect on outside earnings. Our identification strategy accounts for the fact that measures of electoral competition are likely to be endogenous in an empirical model of outside earnings. Exploiting the fact that, in German federal elections, voters cast one vote to elect a candidate representing the electoral district and a second vote to determine the strength of parties in the Bundestag, we construct instrumental variables for the degree of electoral competition at the district level. Our results point to a significant impact of electoral competition on outside earnings. An increase in the vote margin in the preceding election by one standard deviation is estimated to increase outside earnings over a four-year term by about 17,900 Euros on average.

The paper is related to a number of contributions dealing with electoral competition and the behavior or decisions of elected officials. Parker (1992) offers a general discussion of the determinants of honoraria income among members of the U.S. Congress, finding no effect of electoral competition. Besley (2004) builds a principal-agent model in which the effect of higher wages on politicians' activities can be analyzed. Gagliarducci et al. (2008) show that Italian politicians who are elected by majority rule show higher effort levels (lower absenteeism) than politicians who are elected in a proportional system. The voting behavior of members of the U.S. Senate is analyzed in Rosenson (2007). Among other things, the author finds that electorally vulnerable members were less likely to vote for their own salaries to increase. Finally, Gagliarducci et al. (2007) point to a positive relation between outside income and absenteeism.

The remainder of the paper is organized as follows. In the next section, we outline our main hypothesis concerning the impact of electoral competition on politicians' behavior. Section 3 describes the institutional background, the empirical model and the data including some descriptive statistics. The results of our empirical analysis are presented in Section 4, and Section 5 concludes. 


\section{The main hypothesis}

Our analysis is based upon the model of the politician as a rational utility-maximizing agent. We assume that politicians receive utility from income (i.e. consumption) and from being in office. We consider a politician's allocation of time between outside occupations, defined as all activity generating earnings exceeding the regular income of legislators, and political work, which is assumed to be all activity related to legislation and campaigning, e.g. giving speeches, working in parliament committees, attending sessions, working in the home constituency, etc. From the point of view of a politician, political work is valuable as it increases the probability of reelection. Since politicians are regularly paid on a lump-sum basis (exceptions are discussed below), income can only be increased by working in some outside occupation. Thus, politicians face a tradeoff between allocating time to outside occupations (i.e. generating income) and political work (i.e. increasing the probability of being reelected).

Based on the framework outlined above, it is straightforward to show that the utilitymaximizing politician will choose an allocation which equates the marginal benefits of both types of activity. ${ }^{4}$ Intuitively, the condition for an optimal allocation of time requires that the marginal hour of political work yields the same utility gain as the last hour spent in an outside occupation. Put differently, a rational choice implies that the (utility-weighed) income increase due to an enhanced reelection probability equals the hourly wage rate in the outside occupation.

In the following, we focus on how political competition affects the tradeoff between outside work and political work. Concerning the operationalization and measurement of competition we adopt the methodology used in the literature, see e.g. Parker (1992), which can be explained as follows. Assume that an incumbent competes with a challenger for a constituency (see below for more information on the institutional background in Germany). Whereas in some constituencies a large majority of voters prefers a candidate over the other, in others the preferences of voters are rather equally distributed. In the former constituency, competition is low because the candidates face low chances to affect the outcome of elections by increased political effort. In the latter, competition is strong since it is more likely that political work or performance will make the difference at the election day.

In the above setting, the degree of electoral competition has a straightforward effect on a politician's optimal allocation of time. If competition is low, the marginal benefit of political work is low. Accordingly, the rational politician will spend more time in outside

\footnotetext{
${ }^{4}$ In a former version of this paper, we derive the hypothesis using a formal model, see Becker et al. (2008).
} 
occupations. However, if competition is fierce, the politician has the incentive to spend more time for activities increasing the probability of being reelected.

Unfortunately, we cannot observe the amount of time politicians allocate to political and outside work. In order to be able to test the above hypothesis, we must rely on the assumption that, conditional on individual characteristics, the wage rate for outside work is equal across politicians. In practical terms this means that, after taking account of a large number of individual characteristics like gender, age, educational attainment, party affiliation etc., the observable variation on outside earnings is assumed to result from differences in terms of time allocated to outside work rather than differences in politicians' wage rates. Effectively, our main hypothesis therefore states that an increase in political competition will result in a decrease in politicians' outside earnings. ${ }^{5}$

A second measurement problem relates to political competition, i.e. current voter preferences across candidates. As these preferences are unobservable, we use the difference between the vote shares of individual candidates in the preceding election as a substitute. To the extent that voter preferences are relatively stable over time, vote margins from past elections should provide us with proxies for current political competition.

While we assume political work and outside income to be substitutes, one might think of cases where political work is directly linked to income generation. For example, politicians may serve their party's or their voters' interest as a (remunerated) board member of large firms or as lawyers and advisors. Furthermore, they may be paid through various channels by interest groups which try to attain certain special treatments ${ }^{6}$ or may be in the position to decide on legal proposals which affect their own income. ${ }^{7}$ We abstract from all linkages between political work and outside income because of the lack of adequate data. However, if outside occupations increase the MPs' probability of being reelected, this will bias our estimations downwards. Thus, if such direct positive linkages between political work and income existed, our estimations would underestimate the negative effect of competition on outside earnings.

\footnotetext{
${ }^{5}$ Of course, differences in outside income may also be driven by unobservables. However, this does only cause a problem if these unobservable characteristics affect both outside earnings and political competition. For a detailed discussion of the issue, we refer the reader to Section 3.3.

${ }^{6}$ This is what Barro (1973) calls "political income". See also Denzau and Munger (1986) for a discussion of interaction between legislators and interest groups.

${ }^{7}$ Ziobrowski $(2002)$ and co-authors $(2002,2004)$ examine the holding of common stock and real estate assets by members of the US Congress.
} 


\section{Empirical approach}

The empirical analysis is tailored to test our main hypothesis. In particular, we want to estimate how outside earnings of professional politicians react to varying degrees of electoral competition. First, we briefly describe the institutional background, with a focus on the federal electoral system in Germany. We then briefly present and describe the data. Finally, we discuss our estimation approach, focussing on the potential endogeneity of our measure of electoral competition and the suggested solution to this problem.

\subsection{Institutional background}

The Bundestag is the legislative branch of the German federal political system (together with the Bundesrat, representing the state governments). The Bundestag is elected every four years. ${ }^{8}$ Each citizen has two different votes, a first vote and a second vote. The first vote is directly attributed to a candidate representing the electoral district. In each electoral district, the candidate obtaining the largest number of first votes is elected to the Bundestag by a direct mandate (even if the sum of all other candidate's votes is larger). This part of the election has features of the majority voting system. With the second vote the elector votes for a party which may then, according to its share of party votes, send candidates from predefined electoral lists into the Bundestag, which has the feature of proportional representation. These electoral lists contain party candidates in a predefined order. ${ }^{9}$ While each directly elected candidate represents one of the 299 electoral districts, candidates on the party lists can only capture the remaining 299 seats of the Bundestag in accordance with their party's overall share of second votes. The position of candidates on the party lists is subject to ballot votes taking place on party conventions. There is a minimum threshold of either $5 \%$ of the national party vote or three direct mandates. ${ }^{10}$

\subsection{Data}

In the following, we discuss the data and present summary statistics. Since our empirical analysis will be concerned only with the 299 directly elected members of Parliament (MPs,

\footnotetext{
${ }^{8}$ The Bundestag cannot be dissolved neither by the government nor by itself. However, the chancellor may ask the President of Germany for new elections of the Bundestag after the Bundestag has rejected her/him asking for a vote of confidence.

${ }^{9}$ Some of the direct mandate candidates are on the electoral lists. Thus, in case they are not elected, it depends on their position on the list whether they enter the Bundestag or not.

${ }^{10}$ In case that a party has less than $5 \%$ votes but three direct mandates, it obtains a number of seats in accordance to its vote share (proportional representation).
} 
henceforth), we report summary statistics only for this subsample of all MPs. Recall that we exclude MPs that have been elected through party lists to obtain a sample of politicians with homogenous perceptions of electoral competition.

Our key variables are outside earnings and electoral competition. The information on outside earnings is obtained from Bundestag (2007). In 2005, the Bundestag decided to publish an annual report on outside earnings received by the MPs. ${ }^{11}$ From 2005 on, each MP must report the number and earnings class of his or her outside occupations. ${ }^{12}$

The report on individual outside earnings classifies each individual job into one of four different categories: regular occupation, position in a company in the private sector, position in a company in the public sector and position in a non-profit association. For each category, we have the number of jobs and, for each job, the information if it is either one-time or at regular intervals, and the amount of payments received according to four intervals $[0 ; 1,000)$, $[1,000 ; 3,500),[3,500 ; 7,000),[7,000, \infty) .{ }^{13}$ Assuming an upper bound of 12,000 Euros for the highest interval, we calculated the amount of outside earnings for each individual MP by using average values for each income category, i.e. 500; 2, 250; 5, 250; 9, 500. ${ }^{14}$

Table 1: Descriptives on key variables

\begin{tabular}{lrrrr}
\hline Variable & Mean & Std. Dev. & Min & Max \\
\hline Outside earnings & 10,501 & 25,254 & 0 & 144,500 \\
Vote margin (first votes, in \%) & 13.7 & 10.5 & 0.1 & 48.1 \\
\hline
\end{tabular}

Note:

Only directly elected candidates included $(\mathrm{N}=299)$.

Regarding electoral competition, the German electoral system suggests to use the first-vote margin, defined as the difference between the vote share that a given MP has received in his electoral district and the vote share of the runner-up. The data refer to the 2005 election and are obtained from Bundeswahlleiter (2008), which is also the data source for results

\footnotetext{
${ }^{11}$ Cf. Bundestag (2006).

${ }^{12}$ The information on outside earnings is available on the webpage of each MP at http://www.bundestag.de/htdocs_e/members/mdb/index.html and it is updated in irregular intervals. We collected this data in fall 2007 and updated the information in the beginning of 2008 to include all outside earnings from 2005-07.

${ }^{13}$ The fact that all earnings above 7,000 Euro enter the same category - beside the legal threat to be punished in case of misreporting - make us confident that the data are reliable. Furthermore, misreporting has probably a high political cost. This became evident when Otto Schily, the former minister of home affairs, lost a lawsuit when he refused to publish his income as a lawyer.

${ }^{14}$ The highest category has no upper bound. Therefore, in order to obtain a measure of outside income in the highest category, we have to make an assumption. We decided to choose a level of 12, 000 Euros, giving us a linearly increasing difference between the category medians. As this choice may induce distortions, we experimented with several alternative upper bound levels. The results do not change qualitatively. In terms of quantitative effects, note that the chosen upper bound level is presumably a conservative guess. In Section 4 , we also briefly comment on changes in our findings if we calculate outside earnings using the lower bounds of each income category, i.e. $0 ; 1,000 ; 3,500 ; 7,000$.
} 
of previous elections and the second vote shares. Table 1 shows descriptive statistics for our key variables. The average directly elected candidate receives outside earnings of about 10,500 Euros per year. The standard deviation of more than 25, 250 Euros indicates that the variation across MPs is substantial. The average first-vote margin is 13.7 percentage points. Again, there is significant variation across politicians.

Table 2: Descriptives on personal and political characteristics

\begin{tabular}{|c|c|c|c|}
\hline Variable & Frequency & $\%$ outside earnings $>0$ & Mean income \\
\hline \multicolumn{4}{|l|}{ Sex } \\
\hline Male & 229 & 0.86 & 12740 \\
\hline Female & 70 & 0.80 & 3178 \\
\hline \multicolumn{4}{|l|}{ Age } \\
\hline median or below & 155 & 0.84 & 10629 \\
\hline above median & 144 & 0.85 & 10365 \\
\hline \multicolumn{4}{|l|}{ Education } \\
\hline High school or less & 49 & 0.82 & 12576 \\
\hline University & 196 & 0.85 & 9709 \\
\hline Ph.D. & 54 & 0.87 & 11587 \\
\hline \multicolumn{4}{|l|}{ Family status } \\
\hline married with children & 179 & 0.88 & 13222 \\
\hline other & 120 & 0.79 & 6444 \\
\hline \multicolumn{4}{|l|}{ Region } \\
\hline West & 234 & 0.82 & 12034 \\
\hline East & 65 & 0.92 & 4987 \\
\hline \multicolumn{4}{|l|}{ Leading position } \\
\hline 0 & 194 & 0.82 & 6073 \\
\hline 1 & 105 & 0.90 & 18684 \\
\hline \multicolumn{4}{|l|}{ Service in committee } \\
\hline 0 & 57 & 0.91 & 25424 \\
\hline 1 & 242 & 0.83 & 6987 \\
\hline \multicolumn{4}{|l|}{ Party } \\
\hline Christian Democrats & 149 & 0.89 & 13150 \\
\hline Other & 150 & 0.80 & 7871 \\
\hline \multicolumn{4}{|l|}{ Terms served } \\
\hline 1 & 43 & 0.79 & 12317 \\
\hline 2 & 95 & 0.79 & 7015 \\
\hline 3 & 61 & 0.92 & 8639 \\
\hline 4 & 33 & 0.88 & 19808 \\
\hline 5 & 67 & 0.88 & 11391 \\
\hline
\end{tabular}

Regarding our control variables, we have collected information on personal characteristics (education, family status, etc.) as well as political variables (party affiliation, number of 
terms served, etc.) from the MPs' webpages. Table 2 reports some descriptive statistics. For each variable, we display the number of MPs, the fraction of MP with strictly positive outside earnings, and the mean income in all relevant categories which we use as controls in the estimations.

A few details stand out. Firstly, male MPs have outside earnings that are more than four times higher than female MPs. Secondly, MPs from West Germany have almost three times higher outside earnings, although MPs from East Germany are more likely to have outside jobs. Thirdly, the income of MPs with a leading position within the party or the parliament (chairman or vice chairman of a political party or a parliament committee) is substantially higher compared to the income of common members of the Bundestag. However, not serving in a committee leads to almost three times higher outside earnings. Fourthly, Christian Democrats have significantly higher income than politicians from all other parties.

\subsection{Estimation approach}

We take a straightforward approach to test the empirical implications of our main hypothesis. The dependent variable is the amount of annual outside earnings, the key explanatory variable is the vote margin. Using a measure for electoral competition based on the outcomes of the preceding election means that politicians are assumed to form expectations on the degree of competition in coming elections based on outcomes of past electoral races.

The main difficulty when estimating the impact of electoral competition on outside earnings is the fact that a MP's ability to earn income from outside work is not only related to the tradeoff between additional income and deteriorating reelection prospects, but will also depend on personal characteristics affecting the productivity of outside work. We account for this by including a vector of additional explanatory variables in our estimation equation. In particular, we control for a number of personal characteristics that might affect the productivity of MPs in generating outside earnings. However, there is no guarantee that including observable characteristics on the right-hand side of an estimation equation relating outside earnings to electoral competition will suffice to provide us with reliable point estimates. The reason for this is that there might be unobservable characteristics that affect the ability to earn market income and, at the same time, correlate with electoral success. To give a straightforward example, some MPs may simply be smarter than others, making them more successful in terms of election outcomes and in terms of generating outside earnings. Since the error term in our estimation equation will account for all unexplained variation in outside earnings, the fact that smartness is (at least to some extent) unobservable will induce correlation between the residual and electoral competition as our key explanatory variable. 
This correlation will render OLS coefficient estimates inconsistent. As described below, we use instrumental variables (IVs) to overcome the potential endogeneity problem.

Based on the discussion of the tradeoff between allocating time to political work and outside occupations, we consider the following linear equation that relates reported outside earnings of MPs to the degree of electoral competition and controls

$$
y_{i}=\alpha+\beta c_{i}+X_{i} \delta+\epsilon_{i}
$$

where $y_{i}$ denotes outside earnings, $c_{i}$ is electoral competition, $X_{i}$ is a vector of control variables, and $\epsilon_{i}$ is the error term. To obtain a reasonable measure for $c_{i}$, we restrict our attention to those MPs who directly represent an electoral district, i.e. who obtained a majority of first votes within their electoral district. This provides us with a sample of 299 MPs who are homogenous in the sense that their perceptions regarding the probability of reelection in coming elections can reasonably be assumed to depend on the district-level degree of competition in the preceding election. As mentioned above, we use the vote margin as a measure for the district-level degree of electoral competition.

Regarding the vector of control variables, $X_{i}$, we use the data on MPs' personal characteristics described in the previous subsection. In addition, we account for political variables like the number of terms served, party affiliation, and service in committees. Furthermore, we include a dummy for East Germany to allow for common regional shocks that might affect the ability to raise income from outside work and to account for a potential impact of regional traditions and beliefs regarding the tradeoff between political effort and outside work.

As discussed above, we suspect that unobserved factors driving both outside earnings and our measure of electoral competition induce correlation between the residual, $\epsilon_{i}$, and $c_{i}$. To deal with this problem, we employ an instrumental variable, $z_{i}$, and estimate the coefficients in equation (1) by two-stage least squares (2SLS). To be a valid instrument, a variable must satisfy two conditions: it must be strongly (partially) correlated with $c_{i}$ once the exogenous explanatory variables are netted out, and it must be exogenous in the structural equation, i.e. $z_{i}$ must be uncorrelated with $\epsilon_{i}$. A valid instrument which is sufficiently strongly correlated with the vote margin will provide us with exogenous variation that can be exploited to overcome the endogeneity problem and to identify the effect of interest.

Our choice of $z_{i}$ rests on the institutional characteristics of the federal electoral system in Germany. In particular, we exploit the fact that voters vote on district-level candidates (first vote) and parties (second vote) at the same time. Recall that candidates who are directly elected by obtaining a majority of (district-level) first votes become members of the 
Bundestag irrespective of their party's overall second-vote share. We exploit this feature and define our instrumental variable, $z_{i}$, to be the share of second votes MP $i$ 's party has obtained within $i$ 's electoral district in the preceding election. $z_{i}$ lends itself as an instrument for $c_{i}$ because both the share of first votes of a given candidate and the share of second votes of the candidate's party will be correlated due to voters casting both of their votes according to party preferences. Moreover, as long as the second vote reflects only party preferences, $z_{i}$ will not be correlated with the residual. The first-stage regression in our instrumental variable estimations thus reads

$$
c_{i}=\gamma+X_{i} \mu+\theta z_{i}+u_{i} .
$$

Intuitively, the IV estimations will use the fitted values from this regression as substitutes for $c_{i}$ in the OLS regression of outside earnings on MPs' characteristics. Hence, the identification of the impact of electoral competition on outside earnings will rely only on that part of the variation in $c_{i}$ which is driven by exogenous variables.

However, one might think of unobserved factors affecting outside earnings, first-vote margins as well as the second vote shares. In this case, $z_{i}$ may not be a valid instrument. To recall the example, one could think of unobserved candidate characteristics which drive up outside earnings and the first-vote share. If, at the same time, the second-vote share of the respective party depends on the popularity of the candidate (voters may tend to vote for the party whose candidate they like most), an instrument which is based on second-vote shares may be endogenous to outside earnings. To cope with this problem, we extend the analysis by using an IV which has been derived from election results prior to 2005. For details, we refer the reader to Section 4 .

\section{Empirical results}

We start the discussion of our empirical results with a set of ordinary least squares (OLS) regressions reported in Table 3. The dependent variable is reported outside earnings of directly elected members of the Bundestag. Specification (1) is a baseline specification that accounts for a number of individual characteristics like age, gender, educational attainment etc. which are known to be important wage determinants in the labor economics literature. The results indicate that an increase in the first-vote margin by one percentage point triggers an increase in outside earnings of about 307 Euros. Furthermore, we find that female MPs receive substantially lower income from outside work compared to their male colleagues, that MPs whose family status is 'married with children' have higher and those from East 
Germany have lower outside income.

The second column reports an estimation where we have added the dummy for MPs with leading positions. This variable might be positively correlated with the vote margin, biasing the vote margin coefficient upwards. However, although the additional explanatory variable is highly significant (with the coefficient carrying the expected positive sign) and more than doubles the adjusted $R^{2}$, the findings regarding the impact of the vote margin are almost unchanged. Among the controls, the dummy for MPs from East Germany is now not statistically different from zero. We proceed by adding the count of committee memberships as a further right-hand side variable. Since serving in committees is time consuming, we expect this variable to reduce outside earnings and, if omitted from the regression, to induce a downward bias in the vote margin effect. Again, however, the inclusion of the additional control seems to have little impact on our findings. Column (4) adds a dummy for Christian Democrats. Since voting patterns could differ across regions depending on the dominant party, the dummy could also be correlated with the vote margin. The results do not provide evidence for this, though, with the coefficient of the vote margin almost identical to the previous specifications.

Finally, Column (5) reports a regression where we have added the number of terms served. We expect this variable to negatively affect outside earnings (because an MP's link to the relevant job market environment becomes weaker the longer he is out of his original occupation). Since more senior MPs should also benefit more from the common incumbent advantage and, therefore, face higher vote margins, omitting the number of terms served is expected to bias the coefficient of the vote margin downwards. The evidence supports this notion, with the key effect of interest now being estimated to be significantly larger. Note also that the estimate is now significant at the 5 percent level.

To summarize the findings obtained so far, we note that the OLS estimates of the effect of the vote margin on the level of outside earnings varies in a predictable way with the chosen specification. This extends also to the inclusion of additional control variables like, for instance, a full series of dummy variables for the MPs' original occupations and a full series of state dummies instead of the dummy for East Germany. Even if we include all these additional regressors to the specification in Column $(5),{ }^{15}$ we still find that the vote margin has a substantial positive impact on outside earnings. We also checked whether redistricting between the 1998 and 2002 elections has any effect on outside earnings (one could think of MPs having to do more political work in order to support their popularity after a (partly)

\footnotetext{
${ }^{15}$ We do not report these results here because, due to the limited number of degrees of freedom, we cannot include the additional regressors in the IV estimations reported below. In order to facilitate comparison of estimation outcomes across specifications, we decided to report estimations with a limited number of regressors for the OLS estimations, too.
} 
Table 3: Impact of electoral competition on outside earnings (OLS)

\begin{tabular}{|c|c|c|c|c|c|}
\hline Dependent variable: $\mathrm{O}$ & $\begin{array}{l}\text { de earnin } \\
\text { (1) }\end{array}$ & $\begin{array}{l}\text { of directl } \\
(2)\end{array}$ & $\begin{array}{c}\text { elected M } \\
\text { (3) }\end{array}$ & $\begin{array}{c}\text { nbers of } \mathrm{P} \\
\text { (4) }\end{array}$ & $\begin{array}{c}\text { rliament } \\
(5)\end{array}$ \\
\hline Vote margin & $307.4^{\star}$ & $310.3^{\star}$ & $314.2^{\star}$ & $308.3^{\star}$ & $352.6^{\star \star}$ \\
\hline & $(174.6)$ & $(165.5)$ & $(164.6)$ & $(165.4)$ & $(168.0)$ \\
\hline Female & $-6701^{\star \star \star}$ & $-7287^{\star \star \star}$ & $-7379^{\star \star \star}$ & $-7273^{\star \star \star}$ & $-7051^{\star \star \star}$ \\
\hline & $(2100)$ & $(2178)$ & $(2167)$ & $(2280)$ & $(2247)$ \\
\hline Age & -8.11 & -51.7 & -71.9 & -67.2 & 104.8 \\
\hline & $(162)$ & $(160.4)$ & $(158.2)$ & $(159.5)$ & $(192.5)$ \\
\hline University & -1208 & -3334 & -4404 & -4382 & -4220 \\
\hline & $(3991)$ & $(3884)$ & $(3844)$ & $(3842)$ & $(3847)$ \\
\hline Ph.D. & -1279 & -3512 & -4208 & -4213 & -3916 \\
\hline & $(4897)$ & $(5024)$ & $(5092)$ & $(5094)$ & $(5110)$ \\
\hline Married with children & $5155^{\star}$ & $5047^{\star}$ & $4839^{\star}$ & $4699^{\star}$ & $4646^{\star}$ \\
\hline & $(2634)$ & $(2601)$ & $(2588)$ & $(2606)$ & $(2600)$ \\
\hline East Germany & $-5023^{\star \star}$ & -3410 & -2042 & -1888 & -1329 \\
\hline & $(2349)$ & $(2297)$ & $(2226)$ & $(2251)$ & $(2225)$ \\
\hline Leading position & - & $12728^{\star \star \star}$ & $10989^{\star \star \star}$ & $10948^{\star \star \star}$ & $12607^{\star \star \star}$ \\
\hline & & $(3580)$ & $(3386)$ & $(3426)$ & $(3669)$ \\
\hline Serves in committee & - & - & $-5599 \star \star$ & $-5618^{\star \star}$ & $-6311^{\star \star \star}$ \\
\hline & & & $(2343)$ & $(2338)$ & $(2408)$ \\
\hline Christian Democrat & - & - & - & 771.7 & 1387 \\
\hline & & & & $(2845)$ & $(2723)$ \\
\hline Number of terms served & - & - & - & - & $-2362^{\star}$ \\
\hline & & & & & $(1269)$ \\
\hline Adjusted $R^{2}$ & 0.042 & 0.096 & 0.115 & 0.113 & 0.120 \\
\hline Sample size & 299 & 299 & 299 & 299 & 299 \\
\hline
\end{tabular}

change in their constituency). However, a dummy for the 175 electoral districts affected by redistricting between 1998 and 2002 proves to be far from being significant, leaving us with an estimate for the vote margin effect on outside earnings of 366.7 (168.9), which is almost identical to the result reported in Column (5). ${ }^{16}$

So far we have ignored the main identification problem, i.e. the potential endogeneity of the first-vote margin as our measure for electoral competition. Table 4 reports results for instrumental variables estimations that account for this problem.

We show three specifications that differ in terms of the sample used for estimation and the instrument employed in the first stage regression. Column (1) depicts the results for a 2SLS estimation using the full sample of 299 directly elected MPs, where we have instrumented the

\footnotetext{
${ }^{16}$ Moreover, we experimented with the number of outside jobs as dependent variable rather than the level of outside earnings. We did not find a significant impact of the vote margin, though. A possible explanation for this is the potentially large degree of heterogeneity across jobs which makes aggregation difficult.
} 
first-vote margin with the share of second votes of a politician's own party, $z_{2005}$, obtained from the 2005 election. With a single IV, the coefficient of the first-vote margin is exactly identified, and we cannot test for instrument validity. Note, however, that $z_{2005}$ is strongly partially correlated with our measure for electoral competition, with a coefficient of 1.50 and a standard error of 0.05 in the first stage regression. Moreover, the corresponding $F$-statistic of the first stage regression is about 792, suggesting that $z_{2005}$ is a strong instrument for the first-vote margin. Turning to our key variable of interest, we note that the coefficient of electoral competition is about 424, significantly larger than the corresponding value in the baseline OLS estimation (Column (5) in Table 3). Calculated over a four-year term, we find that a one-standard deviation increase in the first-vote margin triggers a remarkable increase in outside earnings of about 17,900 Euros. Note also that the point estimate is significant at the $5 \%$ level.

As mentioned above, one may question the validity of our instrument by arguing that secondvote shares are (partly) driven by preferences over candidates in the respective electoral district. This may induce correlation between the instrument and the residual in the main estimation equation, leaving us with an invalid instrument. Our strategy to cope with this problem is to use election results from the 1990 elections to construct the instrumental variable $z_{1990}$ (again defined as the second-vote share of the respective MP's party), and to re-estimate the model using only MPs which did not run in the 1990 election. In general, the unobserved factors driving the potential correlation between the instruments and the residual in the estimation equation should become less prevalent the more distant elections are used to generate the IVs, suggesting the first federal elections after re-unification as the most distant that can reasonable be used for our purpose. Furthermore, when using a sample that contains only MPs who did not run in the 1990 election, it is no longer possible for unobserved, candidate-specific effects to spoil our identification. This is because the sample of MPs who actually contribute to the regression in terms of observations on outside earnings and first-vote margins has nothing in common with the political personnel at the time of the elections we exploit for constructing our instrumental variable.

Due to redistricting between 1998 and 2002 and the exclusion of the more senior MPs running in 1990, the effective sample size is reduced to 90 observations. To disentangle the effect of the change in the composition of the sample and the change in the IV, we report an estimation using the reduced sample and $z_{2005}$ as the instrument for the vote margin in Column (2), and an estimation with the same sample, but $z_{1990}$ as IV in Column (3).

Before turning to the estimation results, it is useful to have a look at Table 5, displaying the means for the key variables in the different samples. We conduct a two-group meancomparison $t$-test between the two subsamples and note that MPs who did not run in 1990 
Table 4: Impact of electoral competition on outside earnings (2SLS)

\begin{tabular}{lccc}
\hline \multicolumn{1}{l}{ Dependent variable: Outside earnings of directly elected } & Members & of Parliament \\
& $(1)$ & $(2)$ & $(3)$ \\
\hline Vote margin & $424.1^{\star \star}$ & $617.9^{\star \star}$ & $594.9^{\star \star}$ \\
Female & $(178.0)$ & $(299.6)$ & $(302.2)$ \\
& $-6814^{\star \star \star}$ & -4677 & -4724 \\
Age & $(2142)$ & $(4162)$ & $(4199)$ \\
& 109.1 & -122.2 & -125.3 \\
University & $(188.2)$ & $(213.4)$ & $(211.8)$ \\
& -4028 & -730.0 & -806.8 \\
Ph.D. & $(3745)$ & $(5720)$ & $(5731)$ \\
& -3694 & 1964 & 1881 \\
Married with children & $(4943)$ & $(7807)$ & $(7785)$ \\
& $4559^{\star}$ & $14994^{\star \star \star}$ & $14989 \star \star \star$ \\
East Germany & $(2579)$ & $(4660)$ & $(4661)$ \\
& -978.2 & 3015 & 2838 \\
Leading position & $(2175)$ & $(4062)$ & $(3802)$ \\
& $12701^{\star \star \star}$ & $15577^{\star \star}$ & $15484^{\star \star}$ \\
Serves in committee & $(3610)$ & $(6316)$ & $(6254)$ \\
& $-6349^{\star \star \star}$ & 4015 & 4038 \\
Christian Democrat & $(2358)$ & $(4015)$ & $(4062)$ \\
& 1177 & 3061 & 3153 \\
Number of terms served & $(2741)$ & $(4163)$ & $(4303)$ \\
& $-2473^{\star}$ & 2660 & 2705 \\
Sample size & $(1272)$ & $(2587)$ & $(2621)$ \\
\hline IV: Second-vote share own party (year) & 299 & 90 & 90 \\
Coefficients of IV $\left(1^{\text {st }}\right.$ stage) & 2005 & 2005 & 1990 \\
& 1.50 & 1.58 & 1.20 \\
& $(0.053)$ & $(0.069)$ & $(0.161)$ \\
& 791.6 & 516.8 & 55.6 \\
\hline
\end{tabular}

Notes:

Sample includes only directly elected MPs. Dependent variable is average annual outside earnings reported for the years 2005-2007, measured in Euro. Standard errors (robust to heteroscedasticity) in parentheses.

Sample in Columns (2) and (3) include only MPs who did not run in the 1990 election. Significance levels:

$\star 10 \%$; ${ }^{\star \star} 5 \%$; ${ }^{\star \star \star} 1 \%$.

have somewhat higher outside earnings and vote margins, are younger by 4.5 years, less likely to hold either a University degree or a Ph.D., to be married with children, to be from East Germany, and more likely to be Christian Democrats. Overall, however, the average characteristics of the two groups seem to be pretty similar. Note in particular that the differences in means for the key variables are not statistically different from zero.

Applying the 2SLS procedure to the subsample of MPs who did not run in 1990 and using $z_{2005}$ as the IV, we obtain a significantly higher point estimate for the impact of the vote margin on outside earnings: with a coefficient of 618, an increase in the vote margin by one standard deviation increases outside earnings over a four-year term by about 26,000 Euros. Comparing this to the estimate from Column (3), where we have used $z_{1990}$ instead 
Table 5: Comparison of means

\begin{tabular}{|c|c|c|c|c|}
\hline Variable & $\begin{array}{c}\text { Full sample } \\
\text { (1) }\end{array}$ & $\begin{array}{c}\text { MPs } 1990 \\
(2)\end{array}$ & $\begin{array}{c}\text { MPs not } 1990 \\
(3)\end{array}$ & $\begin{array}{c}t \text {-test } \\
(4)\end{array}$ \\
\hline Outside earnings & 10501 & 10090 & 11456 & -0.428 \\
\hline Vote margin & 13.7 & 13.4 & 14.3 & -0.743 \\
\hline Female & 0.234 & 0.234 & 0.233 & 0.021 \\
\hline Age & 52.8 & 54.2 & 49.7 & $3.869^{\star \star \star}$ \\
\hline University & 0.655 & 0.689 & 0.577 & $1.861^{\star}$ \\
\hline Ph.D. & 0.180 & 0.172 & 0.200 & -0.571 \\
\hline Married with children & 0.598 & 0.636 & 0.511 & $2.034^{\star \star}$ \\
\hline East Germany & 0.217 & 0.267 & 0.100 & $3.276^{\star \star \star}$ \\
\hline Leading position & 0.351 & 0.339 & 0.377 & -0.631 \\
\hline Serves in committee & 0.809 & 0.804 & 0.822 & -0.370 \\
\hline Christian Democrat & 0.498 & 0.440 & 0.633 & $-3.103^{\star \star \star}$ \\
\hline Number of terms served & 2.95 & 3.15 & 2.47 & $4.007^{\star \star \star}$ \\
\hline Sample size & 299 & 209 & 90 & \\
\hline
\end{tabular}

of $z_{2005}$ in the first-stage regression, we find that the choice of the instrument does not seem to have any sweeping effect on our results. Since the increase in the parameter estimate for the vote margin occurs between Columns (1) and (2), we conclude that it is driven by the switch from the full sample to the subsample, and not by a potentially flawed identification. Hence, we interpret the findings from the instrumental variables estimations as supporting our previous finding of a substantial impact of the vote margin on outside earnings. With evidence suggesting that $z_{2005}$ is a reasonable instrumental variable for the vote margin, we suggest the results in Column (1) to be the most reliable estimates for the effect of interest in this study. We also note that the effect of the vote margin in the subsample of less senior MPs is much stronger than the average effect across all MPs. For those who did not run in the 1990 election, we find a one-standard deviation increase in the first-vote margin to be associated with an increase in outside earnings by 25,100 Euros.

Regarding the robustness of our results to changes in the measurement of electoral competition, we also experimented with various measures describing the degree of effective electoral competition for MPs who are elected through party lists. However, we found it difficult to obtain robust results. This may have to do with the problem that, while we only observe a given MP's position on the relevant list in past elections, the behavior regarding outside work should depend on politicians' expectations on their position in coming election. We also re-estimated the specifications discussed above (using the first-vote margin as the measure for electoral competition) using the sample of MPs who ran as direct candidates but eventually obtained a seat through a party list. In accordance with our expectations, we 
did not find any statistically significant relationship between outside earnings and first-vote margins.

Finally, we would like to stress that all our results are robust to computing individual outside earnings using the lower bounds of the income categories instead of means. ${ }^{17}$ While this provides us with a lower-bound estimate for the actual level of outside earnings, using the specification from Table 4, Column 1, we still obtain a coefficient of 307, significant at the $5 \%$ level.

\section{Conclusion}

Due to asymmetric information between voters and elected representatives, the quality of policy-making crucially depends on the incentives of elected politicians to align their actions with the interests of voters as their principals. Among the various forms of interaction between voters and elected officials, elections are certainly the most important incentivesetting mechanism. However, there is surprisingly little micro-evidence on how politicians react to varying degrees of electoral competition.

This paper adds to the literature in providing evidence on the link between electoral competition and politicians' outside income. Exploiting the remarkable variation in reported outside earnings in a new data set covering the members of the German Bundestag, we have asked how outside earnings of MPs who represent electoral districts and are elected by majority rule react to electoral competition. In accordance with predictions focusing on the tradeoff between outside work and reelection prospects, our results point to a significant negative impact of competition on private sector activities of MPs. We find that a ten-percentagepoint decrease in the vote margin decreases annual outside income over a four-year term by about 17,000 Euros on average. To account for the likely endogeneity of our measure for electoral competition, we have employed instrumental variables that are motivated by the specific institutional details of the German electoral system.

To the best of our knowledge, this paper is the first to provide micro-evidence on the effectiveness of competitive pressure in driving down politicians' outside income. Parker (1992) checks for the impact of electoral competition on honoraria income of Congress members in the year 1989, but does not find any significant effect. This finding does not necessarily need to contradict our results, because - besides from the differences in terms of time periods and countries under consideration - honoraria are just a limited, strongly regulated ${ }^{18}$ and

\footnotetext{
${ }^{17}$ Recall that we assumed an upper bound of 12,000 Euros for the highest category.

${ }^{18}$ In 1989, US election laws limited each honorarium to $\$ 2,000$. Representatives are allowed to keep an
} 
specific share in Congress members' total income, whereas we consider all kinds of outside income. Furthermore, our findings are complementary to the evidence in Gagliarducci et al. (2008) on a positive relation between electoral competition and political effort in terms of session attendance. Thus, in the light of evidence presented in related studies, our findings confirm the picture of rational politicians trading the benefits from increased outside earnings against the higher risk of being elected out of office. When political competition gets stronger, the tradeoff between outside income and reelection prospects forces politicians to invest more in political activities and, at the same time, to reduce activities that generate outside earnings.

Though it is tempting to draw the conclusion that an increase in electoral competition would benefit voters, we would like to point to three caveats: Firstly, we have ignored the impact of electoral competition on the self-selection of citizens into political careers. ${ }^{19}$ On the one hand, it may well be the fact that increased competition reduces the average ability of elected politicians. On the other hand, high outside income opportunities may attract candidates who are not primarily interested in political work (adverse selection). We do not have adequate data, though, to analyze this kind of question. Similarly, MPs with high outside earnings may be strategically assigned to constituencies where their party has strong support. ${ }^{20}$ We are confident, though, that this does not play an important role in our case, as direct candidates are elected by local party members in each constituency who usually feel strongly attached to their home constituency and less committed to macro strategies of their federal party administration.

Secondly, we do not know if MPs will re-run for office in the next election (fall 2009) as this information will only become available shortly before the election date. Therefore, we are not able to control for the possibility that last-period opportunism on the part of exiting MPs may underlie or even exaggerate the outside income earning activity.

Thirdly, while our data suggest that politicians devote less time to private sector activities, we do not directly observe whether politicians increase socially productive or socially unproductive political work in response to increased competition (for instance, think of parliamentary work vs. campaigning). Depending on what type of activity benefits most from the reduction in private sector work, the impact on the welfare of voters may be quite dif-

amount of honoraria of 30 percent of their salary, senators are allowed to keep 40 percent.

${ }^{19}$ If competition drives down outside income, the decision to become politician may be affected. E.g., Fiorina (1994) finds that higher compensation increases the number of Democrats in legislation. Part of the analysis in Besley (2004) is concerned with the decision of high-ability-citizens to candidate for office, see also Besley (2005) as well as Poutvaara and Takalo (2007). Further contributions in this field are Messner and Polborn (2004), Caselli and Morelli (2004), Diermeier et al. (2005) as well as Mattozzi and Merlo (2007a, 2007b).

${ }^{20}$ Note that our IV estimation based on MPs who did not run in 1990 does not rule out this possibility. 
ferent. Hence, there remains plenty of scope for future research on the role of incentives in the political sphere.

\section{References}

Barro, R. J. (1973). The control politicians: An economic model, Public Choice 14: 19-42.

Becker, J., Peichl, A. and Rincke, J. (2008). Politicians' outside earnings and electoral competition, CPE Discussion Papers 08-3 .

Besley, T. J. (2004). Paying politicians: Theory and evidence, Journal of the European Economic Association 2(2-3): 193-215.

Besley, T. J. (2005). Political selection, Journal of Economic Perspectives 19(3): 43-60.

Bundestag (2006). Act on the legal status of Members of the German Bundestag.

URL: http://www.bundestag.de/htdocs_e/parliament/function/legal/memlaw.pdf

Bundestag (2007). Members of the German Bundestag.

URL: http://www.bundestag.de/htdocs_e/members/mdb/index.html

Bundeswahlleiter (2008). Bundestagswahlen.

URL: http://www.bundeswahlleiter.de/de/bundestagswahlen/

Caselli, F. and Morelli, M. (2004). Bad politicians, Journal of Public Economics 88(34): 759-782.

Couch, J., Atkinson, K. and II, W. S. (1992). Ethic laws and the outside earnings of politicians: The case of Alabama's "legislator-educators", Public Choice 73(2): 135-145.

Denzau, A. T. and Munger, M. C. (1986). Legislators and interest groups: How unorganized interests get represented, American Political Science Review 80(1): 89-106.

Diermeier, D., Keane, M. and Merlo, A. (2005). A Political Economy Model of Congressional Careers, American Economic Review 95(1): 347-373.

Fiorina, M. P. (1994). Divided government in the American states: A byproduct of legislative professionalism?, American Political Science Review 88(2): 304-316.

Gagliarducci, S., Nannicini, T. and Naticchioni, P. (2007). Outside income and moral hazard: The elusive quest for good politicians, Working Paper.

Gagliarducci, S., Nannicini, T. and Naticchioni, P. (2008). Electoral rules and politicians' behavior: A micro test, IZA Discussion Paper No. 3348 . 
Kunicova, J. and Rose-Ackerman, S. (2005). Electoral rules as constraints on corruption, British Journal of Political Science 34(4): 573-606.

Mattozzi, A. and Merlo, A. (2007a). Mediocracy, NBER Working Paper No. 12920 .

Mattozzi, A. and Merlo, A. (2007b). Political careers or career politicians, NBER Working Paper No. 12921.

Messner, M. and Polborn, M. (2004). Paying politicians, Journal of Public Economics 88(12): 2423-45.

Milesi-Ferretti, G., Perotti, R. and Rostagno, M. (2002). Electoral systems and public spending, Quarterly Journal of Economics 117(2): 609-657.

Myerson, R. (1993). Effectiveness of the electoral systems for reducing government corruption: A game-theoretic analysis, Games and Economic Behavior 5(1): 118-132.

Parker, G. (1992). The distribution of honoraria income in the U.S. congress: Who gets rents in legislatures and why, Public Choice 73(2): 167-181.

Persson, T. and Tabellini, G. (1999). The size and scope of government: Comparative politics with rational politicians, European Economic Review 43(4-6): 699-735.

Persson, T. and Tabellini, G. (2000). Political Economics: Explaining Economic Policy, MIT Press, Cambridge and London.

Persson, T. and Tabellini, G. (2003). The Economic Effects of Constitutions, MIT Press, Cambridge and London.

Poutvaara, P. and Takalo, T. (2007). Candidate quality, International Tax and Public Finance 14(1): 7-27.

Rosenson, B. (2007). Explaining legislators' positions on outside income limits: Voting on honoraria ceilings in the U.S. Senate, 1981-1983, Public Choice 133(1-2): 111-128.

Ziobrowski, A. J. (2002). Real estate holding of United States Senators, Appraisal Journal 70: $76-85$.

Ziobrowski, A. J., Cheng, P., Boyd, J. W. and Ziobrowski, B. J. (2004). Abnormal returns from the common stock investments of the U.S. Senate, Journal of Financial and Quantitative Analysis 39(4): 661-76.

Ziobrowski, A. J. and McAlum, H. (2002). The real estate portfolio of the United States House of Representatives, Journal of Real Estate Research 24(1): 97-115. 